\title{
Development of Early Childhood Physical Activity Game Model
}

\author{
Pramono \\ Early Childhood Education \\ Universitas Negeri Malang \\ Malang, Indonesia \\ pramono.fip@um.ac.id
}

\author{
Eny Nur Aisyah \\ Early Childhood Education \\ Universitas Negeri Malang \\ Malang, Indonesia \\ eny.nur.fip@um.ac.id
}

\begin{abstract}
This study aims to develop a model of physical activity play in early childhood learning. This research was carried out in several stages consisting of literature review, relevant research, field study, drafting of the model, and expert validation. The results of the study are physical activity game models in early childhood learning. The physical activity game model in learning for early childhood in the form of 5 games a) playing 1 there are 7 games, b) playing 2 and 7 games, c) playing 3 there are 9 games, d) playing 4 there are 8 games, e) playing 3 ad 5 game. Based on the results of the validation of the physical activity game model in early childhood learning for group $\mathrm{A}$ in the model concept, model principles, model objectives, model characteristics, model implementation instructions are very valid.
\end{abstract}

Keywords- model, physical activity, early childhood education

\section{INTRODUCTION}

Early childhood education is the most basic education because the development of children in the future will be largely determined by various meaningful stimulations given early. Early childhood education is basically education organized with the aim to facilitate the growth and development of children, thoroughly or emphasize the development of all aspects of the child's personality.

Education for early childhood must be able to develop all aspects of child development including cognitive, language, arts, social-emotional, and motoric children. Early childhood education should provide pleasant, meaningful, and warm experiences like those given by parents in a home environment. In order for education from early childhood to be carried out optimally, a planned program is needed that provides a number of learning experiences through guidance from people who have special skills in educating children.

The development that occurs in children includes the development of basic abilities development and behavioral and development. Behavioral development includes the development of religious and moral values, emotional social development, and independence. Development to get to know the religion that is embraced and to get used to worship.

In the development of moral values is the development of noble and bad behavior. In the development of children's behavior is given habituation in implementing the good behavior in everyday life. The development of basic abilities is a learning activity that is prepared to improve the ability of children's creativity which includes physical motoric, cognitive, language, social-emotional development, and art. Cognitive development is a development to have general knowledge and science, knowledge of the shape of the pattern, color, size, and knowledge of numbers, letters and letters. Social-emotional development is a development for the right way to get along with others. Physical and motor development is a development to have gross and fine motor skills and can grow optimally. The existence of early childhood education is expected to help optimize the development of various children's potential.

The implementation of learning in early childhood is carried out using an integrated approach. The development of the playing model of physical activity in early childhood is a learning model that integrates the entire scope of development that is found in early childhood in one unit by using an appropriate theme. This means that in the implementation of learning for early childhood education there is no separation between each scope of development and in its implementation using themes that are appropriate to the learning objectives.

In carrying out a learning activity a teacher carries out learning activities that integrate the scope of child development that is associated with a particular theme. Learning models like this require the teacher to be able to carry out learning activities that can encourage the achievement of child development optimally and not only focus on one scope of development. Teachers in compiling the learning process can integrate several areas of child development.

One form of learning model that can be used by teachers in carrying out learning for early childhood is by using the play approach. Learning activities while playing are a key part of the learning process, especially for preschoolers. For that, it is necessary to get attention both for parents and educators so that they can package the material so that it can be impressed as an interesting and fun entertainment.

Childhood is the most important period for subsequent child growth and development. Pleasant situations and conditions are very helpful for educators in instilling values in the formation of all the potential of children such as aspects of motor physical, cognitive, social/emotional development, language, and religious norm values. The potential that children have develops through experience, in the form of motion experience and information experience.

Generally, the experience of movement and information is obtained at school, community, and family through play. The experience of motion experienced by children will have a strong effect on the next life. The motion experiences that children get will last a long time so that all forms of playing or learning at an early age must be taken into account. Characteristics of early childhood motor development are at 
the stage of motion formation and an increase in various variations of the pattern of motion that it has. The stages of the formation of motion in early childhood are the beginning of subsequent motor development. If the motoric development of early childhood is not well developed, it will have an impact on subsequent motor development. Children will experience difficulties in carrying out complex movements such as coordination, balance, agility, and so on.

Gross-motor development as "use progressively more and more skillful of the totality of the body in an activity that involves large muscle groups and that requires spatial and temporal coordination of simultaneous movement of several body segments". Gross-motor development covers mainly abilities used to move the body from one place to another (locomotion) and to move and take objects [1]. The health benefits of engagement in regular physical activity have been widely discussed in the literature, both in relation to children [2].

Coarse motoric aspects can also be developed through play, by playing children can channel energy which indirectly develops all aspects of development, including physical motor, which children do happily without coercion. Through early childhood play can train the body's muscles, stimulate the child's senses, explore, and recognize the environment around the child, besides that, children can reap various benefits for the development of physical-motoric, intelligence, and social-emotional aspects.

The world of children is an active world of moving and playing, "these recommendations are grounded on nations that children are competent, active agents in their own lives" [3]. Added again from the opinion of "Early childhood education is a world that cannot be separated from physical activity by playing"[4]. Based on this opinion it can be concluded that early childhood learning is by playing. Through play, children will gain meaningful movement experience and information experiences.

Children are introduced to knowledge, attitudes that are good through skills, social skills, friends and environment. This process is a provision for real learning activities in elementary school, therefore it is not excessive but wrong when kindergarten children are taught to read, write, and count directly. This has caused many kindergartens to prioritize cognitive and affective development rather ignore the development of physical fitness or motoric activity of children.

The physical activity game model in early childhood learning is mostly done in the form of play. Early childhood can play while learning. This aims to create an interesting and pleasant impression. The benefits of using the physical activity game model with a playful approach are that it can create a pleasant learning atmosphere and shape good behavior, provide more freedom in physical activities and be active in learning, motivate children to move and explore. Move voluntarily and happily.

Based on these problems it is necessary to conduct research to determine the model of early childhood learning with a physical activity approach. Research conducted in the form of development of learning models that can achieve child development.

The development of a game model of physical activity in early childhood learning is expected to produce a learning model that motivates children to be actively involved in learning and enjoy physical activities. The need for active children become healthier and spirit. In addition, the achievement of child development and achievement.

\section{METHOD}

\section{A. Development Model}

This research analyzes qualitative data to develop new variables, to identify the types of scales that may have instruments or to form information categories that will be explored further in the quantitative phase.

Development Research, wherein this development research researchers develop a product based on a product that has been developed before and then by reviewing the literature and studies from experts to refine, adjust to the existing and future needs. Researchers involve only experts in developing these products so that they can produce products in the form of developing physical activity play models for early childhood. In the selected R \& D research model, the development research model developed by Borg \& Gall [5].

In product research and development that is produced or validated in the form of model concepts, model principles, model objectives, model characteristics, model implementation instructions, types of games easily understood by teachers, Games 1 to 5, types of games interesting to learners, game 1-5, whether the evaluation tool on the physical activity assessment learning model is appropriate to use.

\section{B. Development Procedure}

The development research procedure conducted in Early Childhood Education (ECE) with the title "Physical activity play model in learning for early childhood" is a procedure adopted by researchers in making learning models of physical activity learning models in early childhood learning. The development research procedure used in this study can be done more simply by involving the main steps which include:

1. Conduct research and data/information collection with literature studies, observations, discussions, and field studies, as a basis for developing prototypes of physical activity game models in early childhood learning.

2. Conduct planning/planning, formulation of the objectives to be achieved and research steps including the development and design of a feasibility test on products of physical activity game models in early childhood learning.

3. Development of the initial product design of physical activity game models in learning for early childhood to be tested, including learning materials/resources, instruments needed to be evaluated by 2 early childhood learning experts, 2 physical motorists, and 1 evaluation instrument expert.

4. Validate the initial product design before being tested (instrument use test).

5. Design revision after expert validation. 
6. Initial field trial (small group) using 1 group A ECE which is conducted to collect data. At this stage data is collected through interviews, observations, and questionnaires, then the data is analyzed to find its effectiveness.

7. Revise the initial product based on the results of small group trials.

8. Conduct field trials (large group test) with the number of subjects of 5 ECE groups in A Kindergarten.

9. Test the effectiveness of the model using experimental research.

Adaptation to these stages from the 9 steps that have just been implemented is only in stages 1 through step 5. The steps or procedures taken in the implementation of the research model of physical activity play in early childhood learning.

\section{Data analysis technique}

Validity and reliability tests are used to test data that uses questionnaires to see the questions in the questionnaire filled in by the respondent are feasible or not the questions have been used to retrieve data. Validity test should be done on each question item in the validity test. The result of $r$ counts compared to $r$ table where $\mathrm{df}=\mathrm{n}-2$ with sig $5 \%$. If $\mathrm{r}$ table $<\mathrm{r}$ counts then it is valid.

While reliability is a measure of the stability of the respondent's consistency in answering things related to the constructs of questions which are the dimensions of a variable and arranged in a questionnaire form. Reliability tests can be carried out jointly on all questions. If the Alpha value is $>0.60$ then it is reliable. In testing the validity and reliability using the help of SPSS 20 or 21 application tools. With the following steps, (1) data entry into SPSS, (2) fill in the data on the cell or column that is available, (3) save data, (4) processing data, (5) save output, and (6) SPSS output and analysis.

\section{RESULT AND DISCUSSION}

Expert validation in the form of model concepts, model principles, model objectives, model characteristics, model implementation instructions before being tested. The result of the draft assessment model by the five Validators show that the instrument components are in category of "very valid." The instrument components consist of:

- What is the content of CHAPTER I Basic concept of the model of physical activity in the learning process for early childhood?

- Do the contents of CHAPTER I Principle Model of physical activity play in early childhood learning.

- What is the content of CHAPTER I Objective Modeling of physical activity in early childhood learning?

- What is the content of CHAPTER I Characteristics of the game's physical activity model in early childhood learning?

- What is the strategy CHAPTER II about the Guidelines of the Implementation of the physical activity model for learning in early childhood learning is easily understood by kindergarten teachers?

Based on the assessment of the experts obtained the value of the basic concept aspects of the game's physical activity model in learning for early childhood with a value of 0.80 with a very valid category, the principle of physical activity model in learning for early childhood with a value of 0.8 categories is very valid.

The purpose of physical activity play model in early childhood learning is 0.80 with a very valid category, the characteristics of the physical activity play model in early childhood learning with a value of 0.80 with a very valid category, about the instructions for implementing the physical activity play model in learning for Early childhood is easily understood by the teacher 0.80 with a very valid category. This shows the level of model concept validity, model principles, model objectives, model characteristics, model implementation instructions for early childhood in a very valid category.

A. Expert validation in the form of types of games easily understood by the teacher, from Game 1 to 5.

\section{TABLE I. RESUlT OF EXPERT VALIDATION ASSESMENT}

\begin{tabular}{|c|c|c|c|}
\hline \multirow{2}{*}{$\begin{array}{l}\text { Number of } \\
\text { Question Items }\end{array}$} & \multicolumn{3}{|c|}{ Category } \\
\cline { 2 - 4 } & Very Valid & Medium & Invalid \\
\hline 36 & 21 & 15 & 0 \\
\hline Percentage & $58.33 \%$ & $41.67 \%$ & 0.00 \\
\hline
\end{tabular}

Based on the assessment of the experts (validators) about the types of games easily understood by the teacher, Games 1 to 5 , from 36 questions in the very valid category 21 questions $58.33 \%$, in the valid category 15 questions, and in the invalid category 0 questions $0 \%$.

\section{B. Expert validation in the form of interesting types of games to be performed by students, playing 1-5.}

TABLE II. RESUlT OF EXPERT VALIDATION ASSESMENT

\begin{tabular}{|c|c|c|c|}
\hline \multirow{2}{*}{$\begin{array}{l}\text { Number of } \\
\text { Question Items }\end{array}$} & Very Valid & Medium & Invalid \\
\cline { 2 - 4 } & 27 & 9 & 0 \\
\hline 36 & 75.00 & 25.00 & 0.00 \\
\hline
\end{tabular}

Based on the assessment of the experts (validators) the types of games interesting to do by students, games 1-5, from 36 questions in the very valid category 27 questions $75 \%$, in the valid category 9 questions, and in the invalid category 0 questions $0 \%$.

\section{Expert validation in the form of whether the evaluation tool in the physical activity assessment learning model is appropriate to use}

TABLE III. RESUlT OF EXPERT VALIDATION ASSESMENT

\begin{tabular}{|l|l|l|l|}
\hline Number of & \multicolumn{3}{|c|}{ Category } \\
\cline { 2 - 4 } Question Items & Very Valid & Medium & Invalid \\
\hline
\end{tabular}




\begin{tabular}{|c|c|c|c|}
\hline 49 & 35 & 14 & 0 \\
\hline Percentage & 71.43 & 28.57 & 0.00 \\
\hline
\end{tabular}

\section{CONCLUSION}

Physical activity game models in learning for early childhood are developed based on the elements contained in the learning model. Learning models that include an approach to a broad and comprehensive learning model. Aspects of learning that are developed are cognitive aspects (pairing the same color), motor aspects (walking, running, jumping), and affective aspects (activeness and pleasure in carrying out physical activities) which are carried out with a playful approach for early childhood A. groups. The physical activity game model in learning for early childhood in the form of 5 games a) playing 1 there are 7 games, b) playing 2 and 7 games, c) playing 3 there are 9 games, d) playing 4 there are 8 games, e) playing 3 there are 5 games. Based on the results of the validation of the physical activity game model in early childhood learning for group $\mathrm{A}$ in the model concept, model principles, model objectives, model characteristics, model instructions are very valid.

\section{REFERENCES}

[1] Mariarosaria Galdi, Cristiana D’Anna, Nicolina Pastena, Filippo Gomez Paloma. (2015). Gross-motor skills for potential intelligence descriptive study in a kindergarten. Procedia - Social and Behavioral Sciences 174 ( 2015 ) 3797 - 3804.

[2] Linda Pannekoek, Jan P. Piek, Martin S. Hagger. (2013). The motivation for physical activity in children: A moving matter in need for study. Human Movement Science 32 (2013) 1097-1115.

[3] Davis., et.al. (2009). Early childhood education for sustainability: recommendations for development. International Journal of Ealy Childhood, Vol. 41 No 2, 2009: 113.

[4] Tomoliyus. (2012). Pembuatan alat aktivitas jasmani edukatif, kreatif dan inovatif berbasis budaya dan lingkungan untuk anak TK. Yogyakarta: Fakultas Ilmu Keolahragaan Universitas Negeri Yogyakarta.

[5] Borg and Gall. (2003). Educational Research, An Introduction. New York and London: Longman Inc. 